\title{
A 100-Year Review: The production of fluid (market) milk ${ }^{1,2}$
}

\author{
David M. Barbano ${ }^{3}$ \\ Northeast Dairy Foods Research Center, Department of Food Science, Cornell University, Ithaca, NY 14853
}

\begin{abstract}
During the first 100 years of the Journal of Dairy Science, dairy foods and dairy production dairy scientists have partnered to publish new data and research results that have fostered the development of new knowledge. This knowledge has been the underpinning of both the commercial development of the fluid milk processing industry and regulations and marketing policies for the benefit of dairy farmers, processors, and consumers. During the first 50 years, most of the focus was on producing and delivering high-quality raw milk to factories and improving the shelf life of pasteurized fluid milk. During the second 50 years, raw milk quality was further improved through the use of milk quality payment incentives. Due to changing demographics and lifestyle, whole fluid milk consumption declined and processing technologies were developed to increase the range of fluid milk products (skim and low-fat milks, flavored milks, lactose-reduced milk, long-shelf-life milks, and milks with higher protein and calcium contents) offered to the consumer. In addition, technology to produce specialty high-protein sports beverages was developed, which expanded the milk-based beverage offerings to the consumer.
\end{abstract}

Key words: fluid milk, pasteurization, flavor, shelf life

\section{INTRODUCTION}

In the 50 years before the initiation of the Journal of Dairy Science (JDS), milk processing in the United States had evolved from production of milk, butter, and cheese on farms to a system of local milk assembly in small country factories and creameries for production of market milk, cheese, butter, condensed milk,

\footnotetext{
Received July 24, 2017.

Accepted September 5, 2017.

${ }^{1}$ This review is part of a special issue of the Journal of Dairy Science commissioned to celebrate 100 years of publishing (1917-2017).

${ }^{2}$ Use of names, names of ingredients, and identification of specific models of equipment is for scientific clarity and does not constitute any endorsement of product by authors, Cornell University, or the Northeast Dairy Foods Research Center.

${ }^{3}$ Corresponding author: dmb37@cornell.edu
}

and milk powder. Transportation of milk to local dairy factories was typically done by horse and wagon. As larger cities developed, the demand for market (i.e., fluid) milk by city markets created more of a challenge because of slow transportation and lack of refrigeration. Farms near large cities were able to supply milk for the fluid market and those farms enjoyed a higher price for their milk, whereas farms located far from cities provided milk to produce cheese and butter and received a lower price for their milk. Farms in rural areas had little bargaining power for milk price because of the perishable nature of raw milk. As populations grew in urban areas, the demand for market milk increased and raw milk had to be transported longer distances. The most viable option for rapid transportation of raw milk from rural areas to cities was in large milk cans carried by train in ice-cooled railroad cars. The trains ran daily from country to city. Milk was received at privately owned central market milk processing facilities, where it was heat treated and packaged in returnable glass bottles for home delivery (Figure 1).

At the time of the initiation of JDS in 1917, most cities had market milk processing factories. A network of rural creameries produced cheese, butter, condensed milk, and some milk powder to utilize milk that was not needed to meet demand for fresh market milk. Before JDS and even for the 50 years after its launch, a large amount of information and knowledge from applied dairy science research was published in cooperative extension bulletins published by land-grant universities. A classic land-grant university extension bulletin describing a practical method to measure the fat content of milk was written by S. M. Babcock (1890). At the same time, books on milk and dairy products were published by faculty at land-grant universities. Examples of books that summarized the state of knowledge in milk chemistry, milk quality, and dairy product manufacturing immediately before and in the earlier years of JDS are American Dairying: A Manual for Butter and Cheese Makers by Arnold (1876), Testing of Milk and Its Products by Farrington and Woll (1897), Milk and Its Products by Wing (1904), Modern Methods of Testing Milk and Milk Products by VanSlyke (1906), The Science and Practice of Cheese by VanSlyke and 


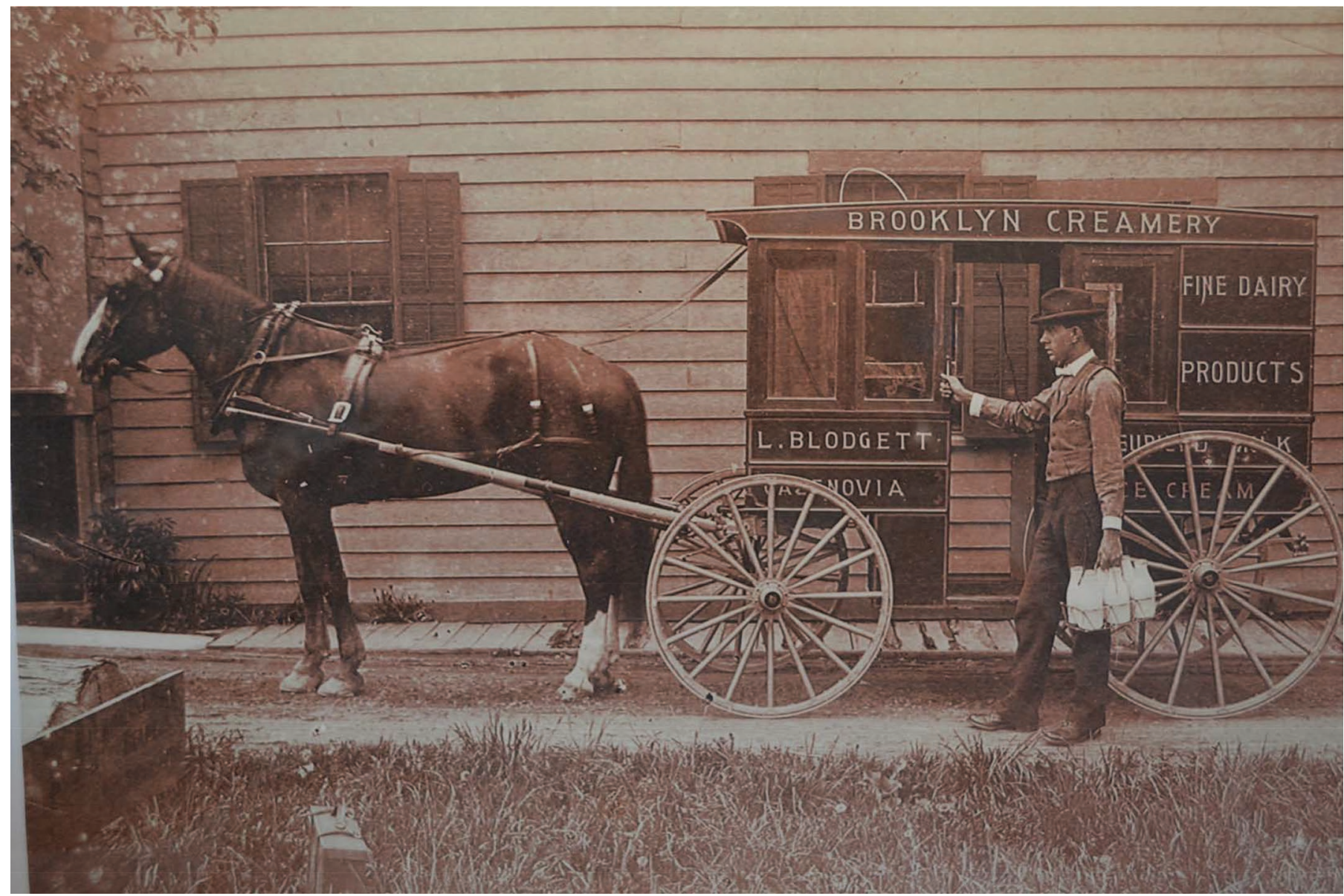

Figure 1. Home delivery of market milk from the Brooklyn Creamery, L. Blodgett, Cazenovia, NY: "Fine dairy products, regulated milk, and ice cream." Color version available online.

Publow (1909), Condensed Milk and Milk Powder by Hunziker (1914), Manual of Milk Products by Stocking (1917), The Book of Cheese by Thom and Fisk (1918) and The Book of Butter by Guthrie (1918), The Technical Control of Dairy Products by Mojonnier and Troy (1922), The Care and Handling of Milk by Ross (1927), and Fundamentals of Dairy Science by Rogers (1928). The scope and function of JDS with respect to market milk and dairy products had to be integrated into the landscape of published literature within the context of other venues of communication of the science of milk and milk products at that time. Before 1917, new knowledge about milk pasteurization (Stocking, 1917), centrifugal cream separation (Wing, 1904), evaporators and dryers (Hunziker, 1914), the Babcock milk fat test for milk payment (Babcock, 1890), and research that determined the relationship between milk composition and cheese yield and cheese quality (VanSlyke and Publow, 1909) were published. It is interesting to note that today, as consumers have more interest in local and minimally processed foods, the basic information and knowledge contained in these early publications is still of use by today's artisan dairy product producers. The challenge for dairy science research requires a balance between (1) developing science-based best practice guidance, as market conditions change and new experience develops in the field, and (2) developing new knowledge and technology that moves the industry forward to find new ways to deliver affordable, safe, and wholesome market milk, dairy foods, and dairy ingredients. Today, more than ever, milk production technologies used at the farm and post-farm milk processing technologies need to be consistent with the desires of consumers and the public in general. Over the years, we have learned that the science may be correct, but ultimately consumer and public opinion balanced against the landscape of differing needs in different areas of the world and societies will allow new technologies and knowledge to be implemented at the appropriate times and places (Appendix Table A1). 


\section{7-JDS MAKES ITS ENTRY INTO THE DAIRY INDUSTRY}

The first few volumes of JDS (before 1920) contained papers that summarized the status of the dairy industry, as the new journal needed to bring together the scientific leaders of the time. This was particularly true for market milk. At the time, there were no national regulations governing fluid milk and dairy products and no national rules for establishing the value and price for milk. The public health department in each city was tasked with protecting the health and safety of residents of the city and, as a result, each city had its own regulations and rules for fluid milk to protect its citizens. The issue of fair and equitable treatment of dairy farmers in a region was outside the scope of local municipalities. Separate from the technical aspects of milk chemistry, microbiology, and processing, changes were happening in the area of regulations for public health and milk pricing.

In the first issue of JDS, there was a report of the Committee on Statistics of Milk and Cream Regulations (Weld et al., 1917) that divided cities by 4 sizes, with the smallest being 5,000 to 25,000 people and the largest $>500,000$ people, and contained a summary of milk ordinances designed to regulate production and sale of milk and cream. The committee concluded that "1) there is a great and urgent need for further research and study on the part of our dairy investigators of some of the problems in the production and handling of milk, and 2) there is a great and urgent need for definite information now available to be placed in the hands of all who are responsible for the laws and ordinances governing production, transportation, handling, and sale of milk." In 1919, Harding and Purchna (1919) published recommendations regarding control of municipal milk supplies.

In the first years of JDS, papers were published that summarized the status of knowledge on various topics, such as butterfat testing (Hunziker, 1917; Bailey, 1918); the daily per capita consumption (a little more than one glass of milk per day; Judkins, 1917); microbiological testing (Breed, 1917; Breed and Brew, 1917; Breed and Stocking, 1917); clarification of milk (Marshall et al., 1920); standardization of the fat content of market milk (VanSlyke, 1917); control of the quality of pasteurized milk and pasteurization of milk by the holder method, and the method of heating milk in final bottle and cooling the milk bottles with a spray of cold water (Hammer and Hauser, 1917; Kelly et al., 1917; Werner, 1917; Smith, 1918); a definition of what is meant by milk quality (Harding et al., 1917); and a report by a committee on development of one uniform score card for milk quality evaluation (Harding, 1920).
In addition, every locality had rules and regulations, and those certified milk regulations were summarized in detail by Stocking (1917). It is interesting to read the New York City regulations of that time and recognize the similarities in scope and content compared with the current Pasteurized Milk Ordinance (PMO; DHHS, 2015; Food and Drug Administration, 2017). The evolution of the details of the current regulations for fluid milk were based on scientific knowledge and research results published over the years in JDS and other research journals.

\section{FLUID MILK RESEARCH IN THE FIRST 50 YEARS}

After the first few years of JDS, research papers start to appear with topics focused on specific challenges in the production, processing, and marketing of milk. A retrospective view in research from the perspective of physics/engineering, chemistry, and biology/microbiology and the development of research tools in each of those disciplines provides an interesting perspective on the change in focus and activity in research across time in the journal. It is interesting to note that some original topics in quality of market milk at that time are similar to the topics today in JDS (e.g., oxidized offflavor in fluid milk and lipolysis). From 1935 through 1940, there were numerous papers in JDS on off-flavors in milk due to metal-catalyzed and light-induced oxidation and lipolysis. The nature and causes of oxidized off-flavor have changed over the years, whereas the fundamental chemistry of oxidized off-flavor development and the negative effect that oxidation has on flavor and consumer acceptability of market milk has remained the same.

Focused research topics related to market milk quality and marketing in the early years of JDS were the milking machine and milk quality (Brew, 1921); identification of the cause of ropy milk (Ward, 1922); the role of the laboratory in pasteurization plants (Hiscock, 1921); action of heat to inactive peroxidase in milk (Spitzer and Taylor, 1923); metals in dairy equipment, their corrosion, and effect on milk flavor (Hunziker et al., 1928); the use of the phosphatase test to verify pasteurization (Hahn and Tracy, 1939; Burgwald, 1941; Hetrick and Tracy, 1947); detection of antibiotics in milk (Kosikowski et al., 1951; Mattick et al., 1955); transfer of feed flavors into milk (MacCurdy and Trout, 1939a,b); and milk pricing and marketing (Spencer, 1956).

In reviewing the papers published in JDS during the first 50 years with a focus on fluid milk, several common topics emerge. Two aspects of milk flavor-lipolysis and oxidation-were common topics of papers in JDS and many papers on these topics were published. 
Brown and Thurston (1939) reviewed the subject of oxidized off-flavor of milk and milk products. The processing and engineering topics of focus in market milk research during the first 50 years were related to the presence of antibiotics in milk (Kosikowski et al., 1951); pasteurization conditions and keeping quality of milk (MacCurdy and Trout, 1939a,b; Tobias et al., 1952); transport and refrigeration systems, steam generation systems, mechanical refrigeration systems (Farrall, 1956); vitamin D fortification of market milk (Weckel, 1940); homogenization (Doan and Mykleby, 1942; Judkins, 1942); and packaging equipment and packaging materials (Henderson, 1955; Johnson, 1955; Farrall, 1956). Farrall (1956) provided an overview of research developments in steam generation with the advent of automatic stokers for coal-fired boilers and the gradual transition to oil- and gas-fired boilers, water treatment system for boiler feeds, the transition from ice and brine cooling systems to ammonia-based mechanical refrigeration systems of improved efficiency, the transition from copper and bronze equipment and pumps to stainless steel, which reduced copper-induced oxidation of milk fat, and the transition from belt-driven to direct electric motor-driven processing equipment. Henderson (1955) summarized the importance of improved public health and reduction of the incidence of foodborne disease caused by milk as a motivation factor for both milk dealers and the US Public Health Service (PHS) in 1923 to establish rules and procedures to ensure safe market milk. The effectiveness of different approaches for pasteurization (flash pasteurization $-160^{\circ} \mathrm{F}$ for 30 to $60 \mathrm{~s}$, the bulk holding process of $145^{\circ} \mathrm{F}$ for $30 \mathrm{~min}$, in-bottle pasteurization, and HTST pasteurization) was being evaluated along with homogenization and different container types (glass vs. paper). By 1955, about $54 \%$ of market milk was sold in paper containers and almost all processing equipment was stainless steel (Henderson, 1955).

During the first 50 years of JDS, there were major changes in distribution of raw and market milk and milk pricing. Technological developments of pasteurization and automated processing equipment, along with improved transportation infrared structure in the United States, changed the marketing and distribution of milk. In 1917, raw milk was produced on farms near cities and market milk was home delivered daily. As centralized milk receiving and cooling and refrigerated rail transportation was improved, raw milk moved longer distances to major cities. As this happened, there were fewer and larger market milk processing plants, fewer and larger milk distributors, and large-scale dairy companies (Spencer, 1956). In 1924, the PHS developed a model regulation known as the Standard Milk Ordinance for voluntary adoption by state and local milk control agencies followed by publication of a code that defined satisfactory compliance. Ultimately, these documents became the basis for the grade A PMO, administered today by the Department of Health and Human Services, PHS, and the Food and Drug Administration (DHHS, 2017). In the early 1930s, there were surpluses of milk and milk strikes. As a result, a farm relief bill called the US Federal Agricultural Adjustment Act of 1933 was passed to stabilize commodity prices and ultimately resulted in the Federal Agricultural Marketing Agreement Act of 1937. These pieces of legislation lead to the establishment of the USDA Federal Milk Marketing Orders that (1) formalized classified pricing for milk used for different purposes, and (2) provided a system of blend pricing that gave milk producers an average milk price that allowed producers both near to and far from large fluid milk-consuming urban areas to share in the overall mix of uses and prices of milk used for different purposes. This legislation would ensure that an adequate milk supply would be available to meet market milk demand, while providing fair and equitable milk pricing to all milk producers, regardless of their location relative to local markets with high fluid milk utilization (i.e., class I).

One of the unique aspects and strengths of the American Dairy Science Association and JDS is that the journal encompasses all aspects of the science of milk production from the feeding of cows, transportation of milk, processing, and marketing of milk and dairy products to provide information upon which politicians and regulators can enact legislation for the delivery of safe and wholesome dairy products to the consumer and ensure a viable and economical production of milk and milk products. As stated in the paper by Weld et al. (1917), the role of dairy scientists is to place science-based information in the hands of all who are responsible for development of laws and ordinances governing production, transportation, handling, and sale of milk. Papers published in JDS and the work and knowledge of the authors of those papers were certainly instrumental in supporting 3 important pieces of dairy legislation in the United States: (1) the PMO of the FDA and PHS; (2) Dairy Product Standards and Definitions in the Code of Federal Regulations; and (3) the USDA Federal Milk Marketing Orders. With time, all of these rules and regulations have been modified and amended based in part on new scientific knowledge published in JDS.

\section{FLUID MILK RESEARCH IN THE SECOND 50 YEARS}

As the milk-producing sector of the dairy industry transitioned to fewer farms with more cows per farm, milk-harvesting practices changed and some of these 
changes affected milk quality. High-line around the barn milking systems in traditional stanchion-type barns caused excessive shear and turbulence of the raw milk before it was cooled and increased the incidence of lipolysis and rancid off-flavors in milk, even though cooling of the milk was faster and bacterial counts were lower. As the number of cows per farm increased, there was a shift away from stanchion barns, where each cow was milked in place, to freestall barns, where the cows walked to milking parlors for milking. This actually resulted in gentler handling of the warm raw milk and faster cooling of raw milk that reduced the issues of lipolysis. In 1978, a review on off-flavors of milk (Shipe et al., 1978) was published in JDS with information on the origin of off-flavors and a discussion of practices to reduce them in market milk. Research was reported on the effect of processing conditions on milk lipolysis (Shipe and Senyk, 1980) and a rapid method for measuring lipolysis (i.e., free fatty acid content) of milk (Shipe et al., 1979). Today, as farms continue to grow in number of cows, our knowledge of dairy cow nutrition increases, and cows are often fed total mixed rations (TMR), it has become common practice to feed by-product (e.g., distillers grains, human food processing by products, whey) and oil seed-based ingredients to increase the energy density of rations for highproducing dairy cows, and by-pass fats in dairy cattle rations. These feeding techniques open up possibilities of new sources of feed-derived off-flavors in milk and are the subject of continuing research that links animal scientists and food scientists in research from farm to consumer.

The movement and marketing of milk changed rapidly with the transition from daily home delivery of milk in returnable bottles to purchasing milk at a supermarket in non-returnable paperboard or plastic containers. The high quality of raw milk, the longer refrigerated shelf life of pasteurized milk, lower distribution costs of centralized distribution, and the growth of supermarket chains allowed the rapid expansion of this marketing channel to the point where today there is virtually no home delivery of milk in the United States. However, this change in marketing and distribution created new technical challenges for market milk. Longer shelf life was needed as distribution was consolidated and milk moved longer distances. This change in marking and distribution required better control of post-pasteurization contamination during processing. The paperboard containers had to increase in size from one quart to half-gallon and gallon sizes. With the desire for longer shelf life, research was needed on paperboard lamination processes that allowed large containers to maintain their rigidity and structure for longer periods. This was a major challenge for the one-gallon paperboard con- tainers. The good news was that paperboard packaging for market milk better protected pasteurized milk from light oxidation than clear glass containers. However, packaging material continued to change and consumers desired one-gallon containers. To provide one-gallon containers, the clear plastic milk jug with a handle emerged. These clear plastic containers were exposed to the continuous high-intensity lighting of dairy cases in supermarkets, which brought back the issue of lightinduced oxidized off-flavor development and fostered research on plastic milk containers with light-blocking components added to the plastic. Today, commercial plastic fluid milk containers (that have light-blocking pigments added to the plastic) are available and used by some processors to protect milk from light oxidation. Fluid milk can be fortified with both vitamins A and D, which are defined as optional ingredients for fluid milks in the Code of Federal Regulations (FDA, 2017). If vitamin $A$ or $D$ is added, the regulations specify the levels and variance in vitamin levels with the framework of good manufacturing practices. The inert carriers of these fat-soluble vitamins that are added to fluid milk can be unsaturated vegetable oil-based and these concentrates may influence milk flavor (Scanlan and Shipe, 1961; Whited et al., 2002). The relationship between vitamin fortification and off-flavors in fluid milk was recently reviewed (Yeh et al., 2017).

Improved cream separator, homogenizer, pasteurizer, and milk filler designs to allow clean-in-place (CIP) operations were developed and this fostered research on better CIP cleaner and sanitizer products, which has progressively allowed market milk processing plants to achieve longer shelf life (17 to $21 \mathrm{~d}$ ) for HTST-pasteurized milk to satisfy the needs of milk marketing and distribution. The elimination of copper and white metal and replacement with stainless steel for processing equipment and farm tanks reduced problems of metal catalyzed oxidized off-flavor development. An approach to maximize fluid milk shelf life is to reduce the age of raw milk, the bacterial count (Boor et al., 1998), and somatic cell count (Ma et al., 2000; Santos et al., 2003a,b; Barbano et al., 2006) of raw milk. As refrigerated shelf life of fluid reached $17 \mathrm{~d}$, it was determined that psychrotrophic spore formers that survived HTST pasteurization were the cause of spoilage and were limiting further increases in shelf life of HTST milk. Huck et al. (2008) used analytical tools of molecular biology to track and identify sources of these heat-resistant organisms from farm to final product and to provide information to control or eliminate these organisms in fluid milk. Ranieri et al. (2009) reported that growth of psychrotrophic spore formers in pasteurized milk was inversely related to HTST processing temperature. Recent progress on pasteurized milk quality improve- 
ment has been reported (Martin et al., 2012). Raw milk quality incentive payment programs for dairy farmers have been developed to pay premiums for low SCC and bacterial counts in raw milk, which has motivated large modern dairy farms to maximize raw milk quality. The preliminary incubation (PI) bacterial count has become a common raw milk quality test, but it has not been shown to have a strong relationship to pasteurized fluid milk shelf life (Murphy et al., 2016). Even today, we do not have a raw milk quality test that can predict final fluid milk product shelf life (Murphy et al., 2016).

While all these structure changes were taking place in the milk production, processing, and marketing channels, the consumer was also changing. Average family size was decreasing and more meals were being eaten away from home. Lifestyle and activity level of the average consumer was changing and consumers became more conscious of calorie intake and fat intake in food products. As a result, the dairy industry offered a line of fluid milk products from $<0.5 \%$ fat (skim milk) to $1 \%, 2 \%$, and whole milk. Research on infrared milk analysis (Biggs, 1967) and light scattering (Shipe, 1972) as rapid methods for measurement of the fat content of milk allowed real-time standardization of fat content of fluid milk and enabled control of the consistency of the composition of reduced-fat fluid milks. Demographics of the population are changing, with an increasing percentage of consumers of Asian and Hispanic origin, who have a high frequency of lactose intolerance created a new challenge for the fluid milk industry. Kosikowski and Wierzbicki (1973) reported a method of hydrolysis of lactose in raw and pasteurized milk. The dairy industry responded by producing lactose-reduced (i.e., 70\%) and lactose-free milks that are created by using the enzyme lactase to break lactose into glucose and galactose and improve digestion of lactose. This process was commercialized as Lactaid (McNeil Nutritionals, Fort Washington, PA) in 1974 by Alan Kligerman. Richmond et al. (1981) reviewed the use of $\beta$-galactosidase in dairy processing. Despite these technologies to make lactose-reduced milk, changes in demographics and lifestyle in the United States did not favor growth of fluid milk consumption. Recently, a combination of partial lactose removal by ultrafiltration combined with enzymatic hydrolysis of the remaining lactose has produced a calorie- and lactose-reduced fluid milk (Fairlife, Chicago, IL).

Consumers continue to want more choices and convenience in milk-based beverages, and competition from non-milk beverages increases. Increased convenience includes both more and better quality single-service milk containers, longer shelf life, greater ability of the product to withstand short-duration temperature abuse, and enhanced nutritional profile. To address increased shelf life, higher temperature (UHT) processing of fluid milk is known to extend shelf life but result in cooked off-flavors that some consumers, particularly children, object to (Chapman and Boor, 2001). Indirect heating versus direct steam injection for UHT processing of fluid milk influences the flavor profile and this trend for consumer dislike of the increased cooked flavor in extended-shelf-life milk continues today and includes both adults and children (Lee et al., 2017). Microfiltration processes have been developed that provide a nonthermal approach to physically removing heat-resistant spores and vegetative bacterial cells from milk that can be combined with minimum pasteurization to achieve longer fluid milk shelf life (Elwell and Barbano, 2006; Caplan and Barbano, 2013).

Consumers are becoming much more nutrition conscious in their beverage choices, and a segment of consumers looks for milk-based products that are low fat and have high protein and calcium contents and reduced calorie content. But those consumers still want the beverage to taste and look great. Research was done to better understand how consumers differentiate milks of different fat content (Phillips et al., 1994a) and the effect of addition of nonfat dry milk (Phillips et al., 1994b) and fat substitutes on sensory properties of low-fat milks (Phillips and Barbano, 1996). The effects of different protein content (Quiñones et al., 1997, 1998) and casein:milk serum protein ratio (Misawa et al., 2016) on fluid milk sensory characteristics were reported. Whiteness of fluid milk had the biggest effect on consumer perception of the fat content of milk (Phillips et al., 1994a), which was confirmed by McCarthy et al., 2017). Having the appropriate sensory and instrumental methods to understand consumer perception (Drake, 2007) and using those metrics to guide both processing and product development represents the practical application of sensory science in the dairy industry.

New milk filtration processing technologies offer milk beverage processors tools to produce new milk-based beverages while minimizing the use of nondairy functional ingredients. Ultrafiltration of skim can remove lactose and concentrate protein and calcium. Removing lactose using ultrafiltration instead of lactose hydrolysis reduces the calorie content and lactose content of a milk-based beverage (Quiñones et al., 1997, 1998) and the first commercial products of this type are available in the US market.

Looking forward, separation of caseins and serum proteins to provide fresh protein concentrates for use in neutral-pH milk casein-based beverages that can be retorted to produce shelf-stable beverages with minimal cooked flavor may be a new opportunity for the fluid milk industry. Use of low-pH, stable, fresh concentrates 
of milk serum proteins to fortify fruit-flavored beverages is another approach to increase beverage consumption of fresh milk protein. As technologies and feeding change on the farm, animal scientists and food scientists need to work together to protect raw milk flavor and quality. Food scientists need to refine existing and develop new processing technologies to meet the everchanging consumer and marketing/distribution needs for milk-based beverages.

\section{SUMMARY}

During the first 100 years of the Journal of Dairy Science, dairy foods and dairy production scientists worked together to publish new data and research that have fostered the development of new knowledge. This knowledge has been the underpinning of both the commercial development of the fluid milk processing industry and regulations and marketing policies for the benefit of dairy farmers, processors, and consumers. During the first 50 years, most of the focus was on producing and delivering high-quality raw milk to factories and improving the shelf life of pasteurized fluid milk. During the second 50 years, raw milk quality was improved further through the use of milk quality payment incentives. Because of changing demographics and lifestyle, consumption of whole fluid milk declined and processing technologies were developed to increase the range of fluid milk products (skim and low-fat milks, flavored milks, lactose-reduced milk, long shelflife milks, and milks with higher protein and calcium contents) offered to the consumer. In addition, technology to produce specialty high-protein sports beverages was developed and expanded the milk-based beverage offerings to the consumer.

\section{REFERENCES}

Arnold, L. B. 1876. American Dairying: Butter and Cheese Makers. Rural Home Publishing Company. Rocherster, NY.

Babcock, S. M. 1890. A new method for estimation of fat in milk, especially adapted to creameries and cheese factories. Bulletin No. 24. Univ. Wisc. Exp. Sta., Madison. WI

Bailey, D. E. 1918. Study of Babcock test for butterfat in milk. J. Dairy Sci. 2:331-373.

Barbano, D. M., Y. Ma, and M. V. Santos. 2006. Influence of raw milk quality on fluid milk shelf life. J. Dairy Sci. 89(E. Suppl.):E15-E19.

Biggs, D. A. 1967. Milk analysis with infrared milk analyzer. J. Dairy Sci. 50:799-803.

Boor, K. J., D. P. Brown, S. C. Murphy, S. M. Koslowski, and D. K. Bandler. 1998. Microbiological and chemical quality of raw milk in New York State. J. Dairy Sci. 81:1743-1748.

Breed, R. S. 1917. Bacteriological methods for market milk analysis. J. Dairy Sci. 1:380-382.

Breed, R. S., and J. D. Brew. 1917. The control of public milk supplies by the use of the microscopic method. J. Dairy Sci. 1:259-271.

Breed, R. S., and W. A. Stocking. 1917. A preliminary report on a series of cooperative bacterial analyses of milk. J. Dairy Sci. 1:19-34.
Brew, J. D. 1921. The milking machine an important factor in milk quality. J. Dairy Sci. 5:412-420.

Brown, W. C., and L. M. Thurston. 1939. A review of oxidation in milk and milk products as related to flavor. J. Dairy Sci. 23:629-685.

Burgwald, L. H. 1941. The phosphatase test-Extent of use in North America. J. Dairy Sci. 25:285-291.

Caplan, Z., and D. M. Barbano. 2013. Shelf life of pasteurized microfiltered milk containing $2 \%$ fat. J. Dairy Sci. 96:8035-8046

Chapman. K. W., and K. J. Boor. 2001. Acceptance of $2 \%$ ultrapasteurized milk by consumers, 6 to 11 years old. J. Dairy Sci 84:951-954.

DHHS (Department of Health and Human Services). 2015. Grade "A" Pasteurized Milk Ordinance. Food Drug Administration, Public Health Services, Milk Safety Branch (HFS-626), College Park, MD

Doan, F. J., and E. W. Mykleby. 1942. A critical study of the United States Health Service definition of homogenized milk and some recommendations. J. Dairy Sci. 26:893-907.

Drake, M. A. 2007. Sensory analysis of dairy foods. J. Dairy Sci 90:4925-4937.

Elwell, M. W. and D. M. Barbano. 2006. Use of microfiltration to improve fluid milk quality. J. Dairy Sci. 89(E. Suppl.):E20-E30.

Farrall, A. W. 1956. Fifty years of progress in dairy plant engineering. J. Dairy Sci. 39:854-863.

Farrington, E. H., and F. W. Woll. 1897. Testing Milk and Its Products. Mendota Book Company, Madison, WI

Food and Drug Administration. 2017. 21CFR131.110: Milk. Accessed Sep. 1, 2017. https://www.accessdata.fda.gov/scripts/cdrh/ cfdocs/cfcfr/CFRSearch.cfm?fr=131.110.

Guthrie, E. S. 1918. The Book of Butter. L. H. Bailey, ed. The Macmillan Company, New York, NY.

Hahn, A. J., and P. H. Tracy. 1939. Controlling pasteurization efficiency through the use of the phosphatase test. J. Dairy Sci $22: 191-200$

Hammer, B. W., and A. J. Hauser. 1917. Studies on the uniformity of heating in the final package method of pasteurization. J. Dairy Sci. 1:462-474.

Harding, H. A. 1920. Should we have a new milk score card? J. Dairy Sci. 4:73-77.

Harding, H. A., R. S. Breed, W. A. Stocking, and E. G. Hastings 1917. What is meant by "quality" milk? J. Dairy Sci. 1:199-217.

Harding. H. A., and M. J. Purchna. 1919. Suggestions regarding the control of municipal milk supplies. J. Dairy Sci. 3:107-121.

Henderson, J. L. 1955. Market milk operations, 1906 versus 1956. J. Dairy Sci. 39:812-818

Hetrick, J. H., and P. H. Tracy. 1947. Effect of high temperature short time pasteurization on some properties of milk. I. Inactivation of phosphatase enzyme. J. Dairy Sci. 31:867-879.

Hiscock, I. V. 1921. Laboratory supervision of pasteurization plants. J. Dairy Sci. 5:372-376.

Huck, J. R., M. Sonnen, and K. J. Boor. 2008. Tracking heat-resistant, cold thriving fluid milk spoilage bacteria from farm to packaged product. J. Dairy Sci. 91:1218-1228.

Hunziker, O. F. 1914. Condensed Milk and Milk Powder. Published by the Author, LaGrange, IL.

Hunziker, O. F. 1917. Specifications and directions for testing milk and cream for butterfat. J. Dairy Sci. 1:38-44.

Hunziker, O. F., W. A. Cordes, and B. H. Nisson. 1928. Metals in dairy equipment: Metallic corrosion in milk products and its effect on flavor. J. Dairy Sci. 12:140-181.

Johnson, A. H. 1955. Contributions of industrial research in dairy manufacturing. J. Dairy Sci. 39:804-811.

Judkins, H. F. 1917. The daily per capita consumption of milk. J. Dairy Sci. 1:246-249.

Judkins, H. F. 1942. Homogenization efficiency test studies. J. Dairy Sci. 26:997-1010.

Kelly, E., J. B. Newman, and G. S. Hine. 1917. Rules and regulations for clean and safe milk supply. J. Dairy Sci. 1:356-360.

Kosikowski, F. V., R. W. Henningson, and G. J. Silverman. 1951. The incidence of antibiotics, sulfa drugs, and quaternary ammonium compounds in the fluid milk supply in New York State. J. Dairy Sci. 35:533-539. 
Kosikowski, F. V., and L. E. Wierzbicki. 1973. Lactose hydrolysis of raw and pasteurized milk by Saccharomyces lactis lactase. J. Dairy Sci. 56:146-148.

Lee, A. P., D. M. Barbano, and M. A. Drake. 2017. The influence of ultra-pasteurization by indirect heating versus direct steam injection on skim and $2 \%$ milks. J. Dairy Sci. 100:1688-1701.

Ma, Y., C. Ryan, D. M. Barbano, D. M. Galton, M. A. Rudan, and K. J. Boor. 2000. Effects of somatic cell count on quality and shelf-life of pasteurized fluid milk. J. Dairy Sci. 83:264-274.

MacCurdy, R. D., and G. M. Trout. 1939a. The effect of holder and flash pasteurization on some flavors of milk. I. The effect of miscellaneous flavors common to commercial raw milk. J. Dairy Sci. 23:843-854.

MacCurdy, R. D., and G. M. Trout. 1939b. The effect of holder and flash pasteurization on some flavors of milk. II. The effect of corn and alfalfa silage flavors. J. Dairy Sci. 23:855-860.

Marshall, C. E., E. G. Hood, A. N. Julian, S. G. Mulkekar, and M. S. Marshall. 1920. Clarification of milk. J. Dairy Sci. 3:245-259.

Martin, N. H., N. R. Carey, S. C. Murphy, M. Weidmann, and K. J. Boor. 2012. A decade of improvement: New York State fluid milk quality. J. Dairy Sci. 95:7384-7390.

Mattick, L. R., E. O. Anderson, and H. L. Wildasin. 1955. A quantitative procedure for determination of inhibitory substances in milk - penicillin. J. Dairy Sci. 38:829-834.

McCarthy, K. S., K. Lopetcharat, and M. A. Drake. 2017. Milk fat threshold determination and the effect of milk fat content on consumer preference for fluid milk. J. Dairy Sci. 100:1702-1711.

Misawa, N., D. M. Barbano, and M. A. Drake. 2016. Influence of caein as a percentage of true protein and protein level on color and texture of milks containing 1 and 2\% fat. J. Dairy Sci. 99:5284-5304.

Mojonnier, T., and H. C. Troy. 1922. The Technical Control of Dairy Products. Mojonnier Bros. Co., Chicago, IL.

Murphy, S. C., N. H. Martin, D. M. Barbano, and M. Weidmann. 2016. Influence of raw milk quality on processed dairy products; how do raw milk quality test results relate to product quality and yield. J. Dairy Sci. 99:10128-10149.

Phillips, L. G., and D. M. Barbano. 1996. The influence of fat substitutes based on protein and titanium dioxide on the sensory properties of lowfat milks. J. Dairy Sci. 80:2726-2731.

Phillips, L. G., M. L. McGiff, D. M. Barbano, and H. T. Lawless. 1994a. The influence of fat on the sensory properties, viscosity, and color of lowfat milks. J. Dairy Sci. 78:1258-1266.

Phillips, L. G., M. L. McGiff, D. M. Barbano, and H. T. Lawless. 1994b. The influence of nonfat dry milk on the sensory properties, viscosity, and color of lowfat milks. J. Dairy Sci. 78:2113-2118.

Quiñones, H. J., D. M. Barbano, and L. G. Phillips. 1997. Influence of protein standardization by ultrafiltation on viscosity, color and sensory properties of skim and 1\% milk. J. Dairy Sci. 80:31423151.

Quiñones, H. J., D. M. Barbano, and L. G. Phillips. 1998. Influence of protein standardization by ultrafiltation on viscosity, color and sensory properties of 2 and 3.3\% milk. J. Dairy Sci. 81:884-894.

Ranieri, M. L., J. R. Huck, M. Sonnen, D. M. Barbano, and K. J. Boor. 2009. High temperature, short time temperatures inversely affect bacterial numbers during refrigerated storage of pasteurized fluid mil. J. Dairy Sci. 92:4823-4832.

Richmond, M. L., J. I. Gray, and C. M. Stine. 1981. Beta-galactosidase: Review of present research related to technological application, nutrition concerns, and immobilization. J. Dairy Sci. 64:1759-1771.

Rogers, L. A. 1928. Fundamentals of Dairy Science. The Chemical Catalog Company Inc., New York, NY.
Ross, H. E. 1927. The Care and Handling of Milk. Orange Judd Publishing Company Inc., New York, NY.

Santos, M. V., Y. Ma, Z. Caplan, and D. M. Barbano. 2003a. Sensory threshold of off-flavors caused by lipolysis in milk. J. Dairy Sci. 86:1601-1607.

Santos, M. V., Y. Ma, and D. M. Barbano. 2003b. Effect of somatic cell count on proteolysis and lipolysis in pasteurized fluid milk during shelf-life storage. J. Dairy Sci. 86:2491-2503.

Scanlan, R. A., and W. F. Shipe. 1961. Factors affecting the susceptibility of multivitamin mineral milk to oxidation. J. Dairy Sci. 45:1449-1455

Shipe, W. F. 1972. Current status of the Milk-o Tester. J. Dairy Sci. $55: 652-655$.

Shipe, W. F., R. Bassette, D. D. Deane, W. L. Dunkley, E. G. Hammond, W. J. Harper, D. H. Kleyn, M. E. Morgan, J. H. Nelson, and R. A. Scanlan. 1978. Off-flavors in milk: Nomenclature, standards, and bibliography. J. Dairy Sci. 61:855-869.

Shipe, W. F., and G. F. Senyk. 1980. Effect of processing conditions on lipolysis in milk. J. Dairy Sci. 64:2145-2149.

Shipe, W. F., G. F. Senyk, and K. B. Fountain. 1979. Modified copper soap solvent extraction method for measuring free fatty acids in milk. J. Dairy Sci. 63:193-198.

Smith, R. S. 1918. Observations on the pasteurization and subsequent handling of milk in city milk plants. J. Dairy Sci. 2:487-503.

Spencer, L. 1956. Significant developments in distribution and pricing of market milk in the United States, 1906-1956. J. Dairy Sci. 39:884-891.

Spitzer, G., and M. C. Taylor. 1923. The effect of heat on the activity of the enzyme peroxidase as found in milk. J. Dairy Sci. 7:234-244.

Stocking, W. A. 1917. Manual of Milk Products. L. H. Bailey, ed. The Macmillan Company, New York, NY.

Thom, C., and W. W. Fisk. 1918. The Book of Cheese. The MacMillan Company, New York, NY.

Tobias, J., E. O. Herreid, and Z. J. Ordal. 1952. A study of milk pasteurization at high temperatures. J. Dairy Sci. 35:356-362.

Van Slyke, L. L. 1906. Modern Methods of Testing Milk and Milk Products. Orange Judd Publishing Company, New York, NY.

Van Slyke, L. L. 1917. The standardization of market milk. J. Dairy Sci. 1:361-370.

Van Slyke, L. L., and C. A. Publow. 1909. The Science and Practice of Cheese Making. Orange Judd Publishing Company, New York, NY

Ward, A. R. 1922. The wide distribution of ropy milk organisms in city milk supplies. J. Dairy Sci. 6:616-623.

Weckel, K. G. 1940. Vitamin D in milk-A review. J. Dairy Sci. 24:445-462.

Weld, I. C., E. H. Farrington, J. A. Gamble, H. E. Ross, and R. C. Potts. 1917. Report of the Committee on Statistics of Milk and Cream Regulations of the Official Dairy Instructors' Association: Presented at its Meeting at Springfield, Massachusetts, October 17, 1916. J. Dairy Sci. 1:45-83.

Werner, P. 1917. A plan for controlling the milk supply in a small town. J. Dairy Sci. 1:284-289.

Whited, L. J., B. H. Hammond, K. W. Chapman, and K. J. Boor. 2002. Vitamin A degradation and light-oxidized flavor defects in milk. J. Dairy Sci. 85:351-354.

Wing, H. H. 1904. Milk and Its Products. L. H. Bailey, ed. The Macmillan Company, New York, NY.

Yeh, E. B., A. N. Schiano, Y. Jo, D. M. Barbano, and M. A. Drake. 2017. The effect of vitamin concentrates on the flavor of pasteurized fluid milk. J. Dairy Sci. 100:4335-4348. 


\section{APPENDIX}

Table A1. Timeline of significant advances in fluid milk marketing

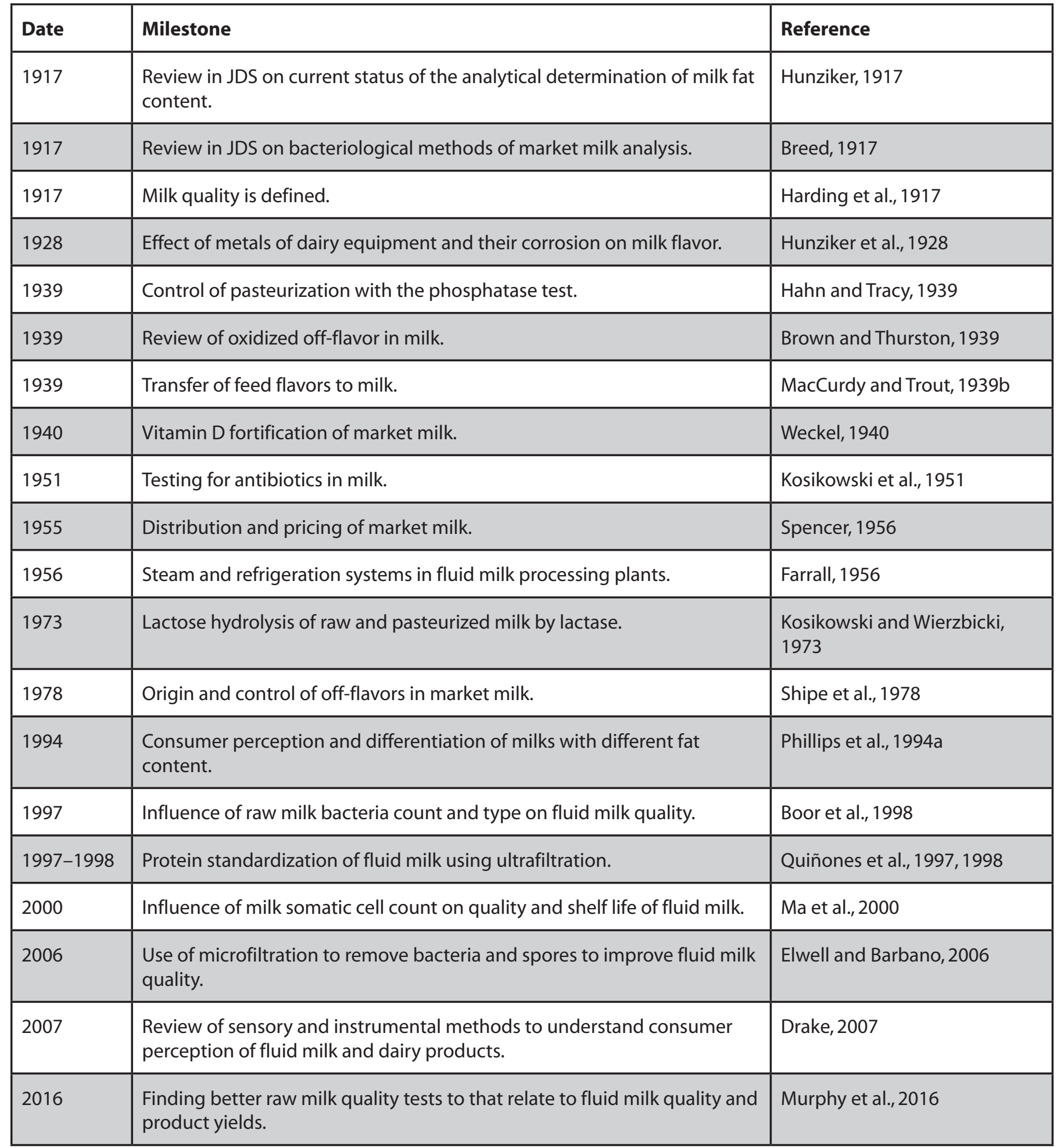

